Published Ahead of Print on May 24, 2021 as 10.1212/WNL.0000000000012201

\title{
Teaching Neurolmages: Notched Delta and Angelman Syndrome
}

Fábio A. Nascimento, MD ${ }^{1}$, Elizabeth A. Thiele, MD, $\mathrm{PhD}^{1}$, and Ronald L. Thibert, DO, $\mathrm{MsPH}^{1}$

1. Department of Neurology, Massachusetts General Hospital, Harvard Medical School, Boston, MA.

Neurology® Published Ahead of Print articles have been peer reviewed and accepted for publication. This manuscript will be published in its final form after copyediting, page composition, and review of proofs. Errors that could affect the content may be corrected during these processes. 
Word count: 143.

Title: 36 characters.

Figures: 1.

Video: 0 .

Keywords: Angelman syndrome, notched delta, EEG, genetic epilepsy.

Corresponding author:

Dr. Fábio Augusto Nascimento e Silva

nascimento.fabio.a@gmail.com; fnascimento@mgh.harvard.edu

Study Funding: The authors report no targeted funding.

Disclosure: F. Nascimento is a member of the Neurology Resident and Fellow Section

Editorial Board. E. Thiele reports no disclosures relevant to the manuscript. $R$ Thibert is a member of the Angelman Syndrome Foundation Scientific Advisory Board. 


\section{Case Description}

We report a 9-year-old boy with a history of Angelman syndrome (AS) with associated epilepsy, behavioral issues, intellectual disability, and sleep disturbance. Genetic testing revealed a methylation imprinting defect, thereby confirming the diagnosis of AS. His seizures were well controlled on monotherapy with clobazam and he underwent a routine EEG (figure), which showed a notched delta pattern.

Notched delta pattern, one of the characteristic EEG findings in AS, is characterized by delta waves intermixed with spikes or sharp waves giving it a "notched" appearance. In the context of a suggestive phenotype, this EEG pattern should raise suspicion for AS. Clinicians should be reminded, nonetheless, that notched delta can be seen in other conditions such as Rett syndrome and different chromosomal abnormalities including $4 p(-)$ syndrome. Lastly, patients with AS may have other patterns on EEG such as persistent rhythmic high-voltage 4-6 Hz activity. $[1,2,3]$

Appendix 1. Authors

\begin{tabular}{|l|l|l|}
\hline Name & Location & Contribution \\
\hline Fábio A. & Massachusetts General & $\begin{array}{l}\text { Conceptualized and designed } \\
\text { study, analyzed and interpreted } \\
\text { data, drafted manuscript. }\end{array}$ \\
\hline $\begin{array}{l}\text { Elizabeth A. } \\
\text { Thiele, MD, PhD }\end{array}$ & Mospital, Boston, MA & Conceptualized and designed \\
& & $\begin{array}{l}\text { study, analyzed and interpreted } \\
\text { data, reviewed manuscript, } \\
\text { supervised study. }\end{array}$ \\
\hline
\end{tabular}




\begin{tabular}{|l|l|l|}
\hline Ron L. Thibert, & Massachusetts General & Conceptualized and designed \\
Do, MsPH & Hospital, Boston, MA & $\begin{array}{l}\text { study, analyzed and interpreted } \\
\text { data, reviewed manuscript, } \\
\text { supervised study. }\end{array}$ \\
& & \\
\hline
\end{tabular}

Teaching Slides -- http://links.lww.com/WNL/B425

\section{References}

[1] Korff CM, Kelley KR, Nordli Jr DR. Notched delta, phenotype, and Angelman

syndrome. J Clin Neurophysiol. 2005;22(4):238-243.

[2] Thibert RL, Larson AM, Hsieh DT, Raby AR, Thiele EA. Neurologic manifestations of Angelman syndrome. Pediatr Neurol. 2013;48(4):271-279.

[3] Vendrame M, Loddenkemper T, Zarowski M, et al. Analysis of EEG patterns and genotypes in patients with Angeiman syndrome. Epilepsy Behav. 2012 Mar;23(3):261265. 


\section{Figure}

Title: Routine EEG shows notched delta pattern [sensitivity 20 uV/mm, LF $1 \mathrm{~Hz}$, HFF $70 \mathrm{~Hz}$, notch on/60 Hz, timebase $30 \mathrm{~mm} / \mathrm{sec}]$.

Legend: EEG: bipolar (A) and referential/average (B) show bilateral occipital, right more than left, delta waves (200-250 uV, $4 \mathrm{~Hz}$ ) superimposed with spikes (arrows) consistent with notched delta.

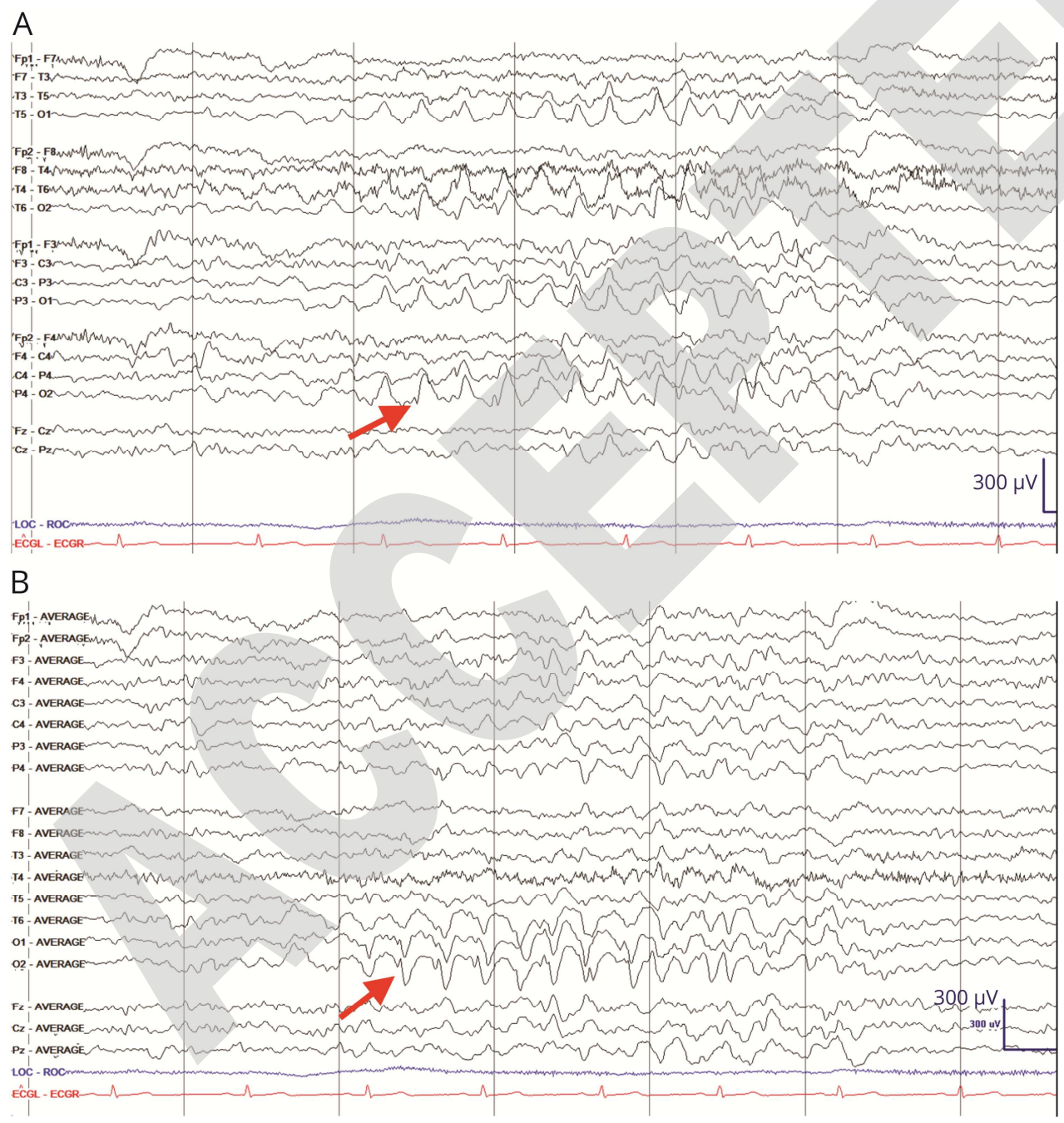




\title{
Neurology
}

\author{
Teaching NeuroImages: Notched Delta and Angelman Syndrome \\ Fábio A. Nascimento, Elizabeth A. Thiele and Ronald L. Thibert \\ Neurology published online May 24, 2021 \\ DOI 10.1212/WNL.0000000000012201
}

This information is current as of May 24, 2021

Updated Information \&
Services

Subspecialty Collections

Permissions \& Licensing

Reprints including high resolution figures, can be found at:

http://n.neurology.org/content/early/2021/05/24/WNL.0000000000012201. citation.full

This article, along with others on similar topics, appears in the following collection(s):

All Genetics

http://n.neurology.org/cgi/collection/all_genetics

EEG

http://n.neurology.org/cgi/collection/eeg

EEG; see Epilepsy/Seizures

http://n.neurology.org/cgi/collection/eeg_see_epilepsy-seizures

Information about reproducing this article in parts (figures,tables) or in its entirety can be found online at:

http://www.neurology.org/about/about_the_journal\#permissions

Information about ordering reprints can be found online:

http://n.neurology.org/subscribers/advertise

Neurology $\AA^{\circledR}$ is the official journal of the American Academy of Neurology. Published continuously since 1951, it is now a weekly with 48 issues per year. Copyright (C) 2021 American Academy of Neurology. All rights reserved. Print ISSN: 0028-3878. Online ISSN: 1526-632X.

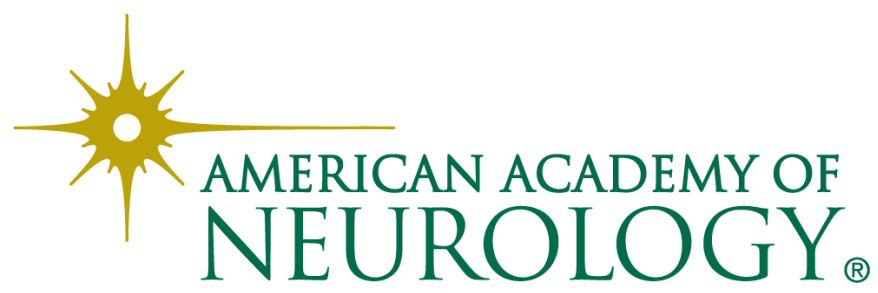

